\title{
Cardiovascular magnetic resonance at 7.0 Tesla in patients with hypertrophic cardiomyopathy - a pilot study
}

Marcel Prothmann ${ }^{1 *}$, Etham Shahid ${ }^{1}$, Agnieszka Toepper ${ }^{1}$, Florian von Knobelsdorff-Brenkenhoff ${ }^{1}$, Andreas Graessl ${ }^{2}$, Jan Rieger ${ }^{3}$, Darius Georg Lysiak², Christof Thalhammer², Till Huelnhagen², Thoralf Niendorf ${ }^{2,3}$,

Jeanette Schulz-Menger ${ }^{1,2}$

From 18th Annual SCMR Scientific Sessions

Nice, France. 4-7 February 2015

\section{Background}

Cardiovascular Magnetic Resonance (CMR) is known to offer additional morphologic information in Hypertrophic Cardiomyopathy (HCM). CMR based myocardial tissue differentiation and the detection of small morphological details is of proven clinical value. MR at a magnetic field strength of 7 Tesla holds the promise to enhance spatial resolution and anatomical detail, but is currently primarily

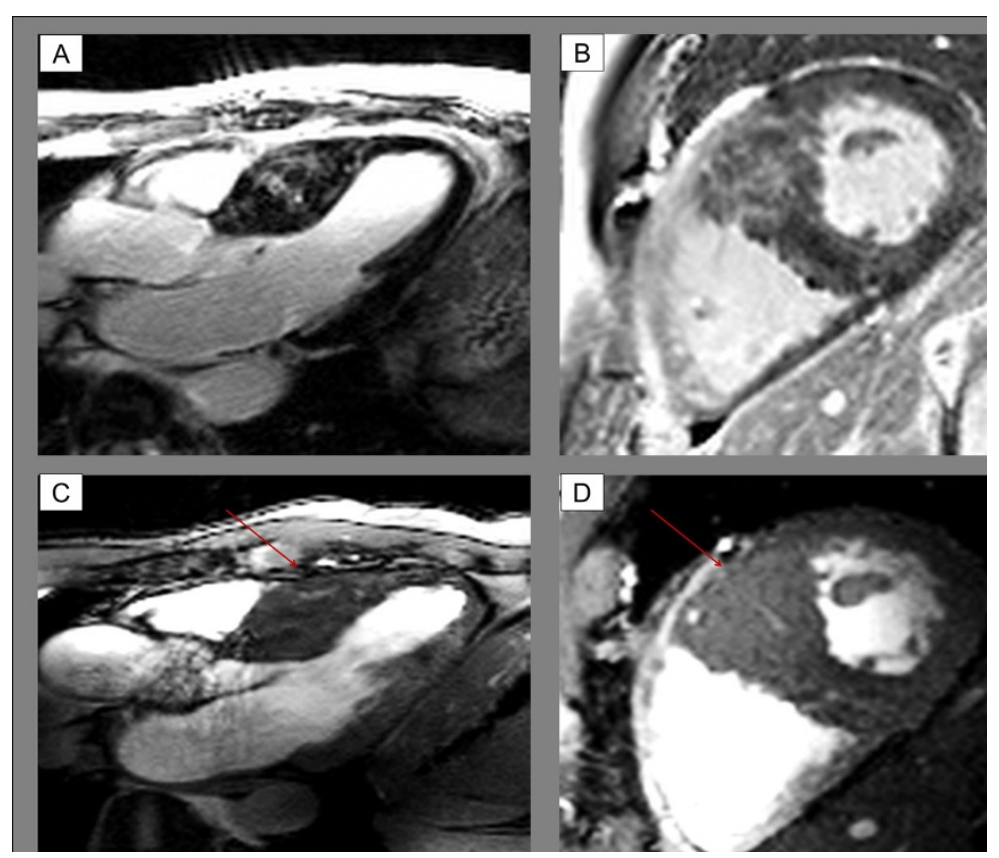

Figure 1 Case example with myocardial crypts- hyperintense signal displays at LGE-images is partly explained by blood. A-B: LGE-imaging at 3T. C-D: CINE GRE at 7T

${ }^{1}$ Cardiology, Charité. Medical Faculty of Humboldt-University Berlin ECRC and

HELIOS Clinics, Berlin, Germany

Full list of author information is available at the end of the article

(c) 2015 Prothmann et al; licensee BioMed Central Ltd. This is an Open Access article distributed under the terms of the Creative 
Table 1 Comparison of LV-function at different field strengths

\begin{tabular}{cccc}
\hline Mean & 3T (biplane) & 7T (biplane) & p-value \\
\hline LVEDV $(\mathrm{ml})$ & 139.9 & 136.7 & 0.232 \\
\hline LVESV $(\mathrm{ml})$ & 53.0 & 51.2 & 0.437 \\
\hline LVM $(\mathrm{g})$ & 187.0 & 174.9 & 0.549 \\
\hline $\operatorname{LVEF}(\%)$ & 62.9 & 59.9 & 0.118 \\
\hline
\end{tabular}

used in brain imaging [1]. CMR at 7.0T has been applied in healthy volunteers $[2,3]$. Here we examine the feasibility of CMR at 7T in patients and demonstrate its capability for the visualization of subtle morphological details which are elusive in today's clinical CMR practice.

\section{Methods}

We screened 131 patients with HCM. 13 Patients with HCM (9 male, $56 \pm 31$ years) and 13 healthy subjects (9males, $55 \pm 31$ years) were scanned at $7 \mathrm{~T}$ and $3 \mathrm{~T}$, a subgroup at $1.5 \mathrm{~T}$ (Siemens, Erlangen, Germany). Cine imaging for the assessment of function and morphology was performed at all field strengths (voxel size $1.4 \times 1.4 \mathrm{~mm}^{2}$ with slice thickness at $7 \mathrm{~T}: 2,5 \mathrm{~mm}$ and $4 \mathrm{~mm}$; at 3 and 1.5 Tesla with $6 \mathrm{~mm}$ ). Late gadolinium enhancement (LGE) was performed at 3T for imaging of fibrosis. Fat-water imaging techniques were employed at $1.5 \mathrm{~T}$ for fat analysis.

\section{Results}

All scans were successful and evaluable. At 3T LV quantification were similar in short axis view and biplane approach (LVEDV, LVESV, LVMASS, LVEF) $(\mathrm{p}=0.232$; $\mathrm{p}=0.437 ; \mathrm{p}=0.549 ; \mathrm{p}=0.118$ ). There was no significant difference between $3 \mathrm{~T}$ and $7 \mathrm{~T}(\mathrm{p}=0.111 ; \mathrm{p}=0.167 ; \mathrm{p}=0.119$; $\mathrm{p}=0.204)$. Typical LGE was detected in $12 / 13(92 \%)$ HCM patients. High spatial resolution CINE imaging at 7.0 T revealed deep but small hyperintense myocardial crypts in the regions for which LGE was detected at 3T. Myocardial crypts occurred in 7/13(54\%) of HCM patients. The presence of fat was excluded as a cause for the hyperintense signal. No crypts were detected for $2 \mathrm{D}$ CINE imaging at 3T.

\section{Conclusions}

7 Tesla MRI is feasible in patients with HCM. High spatial resolution CINE imaging at $7.0 \mathrm{~T}$ affords the detection of subtle myocardial crypts in regions of extended hypertrophy and LGE.

\section{Funding}

N/A.

\section{Authors' details}

${ }^{1}$ Cardiology, Charité. Medical Faculty of Humboldt-University Berlin ECRC and HELIOS Clinics, Berlin, Germany. ${ }^{2}$ Berlin Ultrahigh Field Facility (B.U.F.F.), MaxDelbrueck Center for Molecular Medicine, Berlin, Germany. ${ }^{3}$ MRI.TOOLS GmbH, Berlin, Germany.

Published: 3 February 2015

\section{References}

1. Sinnecker T, et al: Distinct lesion morphology at 7-T MRI differentiates neuromyelitis optica from multiple sclerosis. . Neurology 2012, 79(7):708-14.

2. von Knobelsdorff-Brenkenhoff $F$, et al: Cardiac chamber quantification using magnetic resonance imaging at 7 Tesla-a pilot study. Eur Radiol 2010, 20(12):2844-52.

3. von Knobelsdorff-Brenkenhoff $F$, et al: Assessment of the right ventricle with cardiovascular magnetic resonance at 7 Tesla. J Cardiovasc Magn Reson 2013, 15:23.

doi:10.1186/1532-429X-17-S1-Q108

Cite this article as: Prothmann et al:: Cardiovascular magnetic resonance at 7.0 Tesla in patients with hypertrophic cardiomyopathy - a pilot study. Journal of Cardiovascular Magnetic Resonance 2015 17(Suppl 1): Q108.

Submit your next manuscript to BioMed Central and take full advantage of:

- Convenient online submission

- Thorough peer review

- No space constraints or color figure charges

- Immediate publication on acceptance

- Inclusion in PubMed, CAS, Scopus and Google Scholar

- Research which is freely available for redistribution

Submit your manuscript at www.biomedcentral.com/submit 